József Poór, Gizela S. Susnjar, Agnes Slavic, Zsuzsa Karoliny

\title{
3.7 TRAINING PRACTICE IN CENTRAL AND EASTERN EUROPEAN COMPANIES BASED ON CRANET RESEARCH
}

\begin{abstract}
Summary: In the period of global competition and radical economic changes, human resources and their intellectual capital become a vital resource for organizations. Employees' competence, knowledge, skills, and experience have to contribute not only to the company's financial and marketing success, but also to broader (environmental and social) considerations. The main aim of the Training \& Development as a human resource management (HRM) activity is to help this organizational knowledge acquisition systematically. In Central and Eastern Europe (CEE) HRM managers have a challenging task to implement new methods of effective in-company trainings. The aim of this work is to describe some characteristic features of the training practices in six CEE (Bulgarian, Czech, Hungarian, Serbian, Slovak and Slovenian) countries based on Cranet international research results from the year 2008/10. The findings can provide good benchmark for HR practitioners when designing their new region- and country-specific training approaches.
\end{abstract}

Keywords: training, Central and Eastern Europe, human resources, Cranet

\section{INTRODUCTION}

In the 21 st century when the companies' success mainly depends on the competences and innovativeness of their employees, training and development, as one of the key HRM functions becomes more and more important. Lekovic and Susnjar (2010) note that training includes all those activities, which enable, make easier and accelerate knowledge acquisition necessary for successful business activity. On the other side, Armstrong (2007) defines development as the growth or realization of a person's ability and potential through the provision of learning and educational experiences. Peretz and Caspi (2011) enhance that organizations can follow many paths to secure a skilled and competitive human force. One of the most direct ways is to focus on training and development of human resource management activity. The more advanced the firm's training policy is, and the more efficiently it invests in T\&D, the more likely it is to position itself well on the market (Stavrou and Brewster, 2005).

\section{LITERATURE REVIEW}

According to one school of thought, HRM practices always depend on the context. Based on a longitudinal study conducted in 18 European countries Nikandrou, Apospori and Papalexandris (2005) emphasize that European HRM is characterized by internal variations among clusters of countries and at the same time by external uniformity compared to the rest of the world. Mayrhofer, Sparrow and Brewster (2012) have a similar view, underlining that considering the various elements of external context (national cultures, institutional environment, economic factors, social characteristics, education and political systems) Europe offers a mix of hetero- and homogeneity leading to a unique context for organizational decision makers about HRM matters. Mayrhofer, Sparrow and Brewster (2012) identify the following differences between European and US context of HRM which makes the US HRM techniques only partly applicable in Europe:

- Stakeholder rather than shareholder approach - The American shareholder approach insists on the HRM's ultimate aim to increase organizational performances, evaluated 
based on its impact on corporate strategy, customers or shareholders. The European stakeholder view makes it possible for a greater number of actors to influence HRM decisions based on their legal rights for it. This way the interests of employees, customers, trade unions, creditors and NGOs may be taken into account beside the influence of owners and managers.

- The role of the state - In Europe, state regulations have a more significant influence on a company's HRM activity than in the US. In Europe, the European Union or even regions within a country may have their own HRM policies. Besides, in Europe state is a large employer, too, with special employment practices.

- People's rights in and to their jobs - The majority of the European states guarantee peoples' rights in and to their jobs. In the US with the national culture characterized by high level of individualism and low uncertainty avoidance, there is less legislative control over employee relations.

- Importance of consultation and collective representation - In Europe trade unions are supported by the legislation, and play a more important part in companies' HRM activities than in most part of the world.

Even within Europe there are significant differences in internal and external HRM context and therefore in HRM practice, too. Brewster, Morley and Buciuniene (2010) state that charting the landscape of HRM in Central and Eastern Europe (CEE) is a difficult task. The societies of CEE have undergone through radical changes since the early 1990s, but with rather different outcomes. CEE is now characterized by rising economic heterogeneity and rapidly changing socio-cultural context stressed with privatization, increasing FDI and emerging individualization.

Morley, Minbaeva and Michailova (2012) stress that CEE is not historically well documented in management and human resources literature and contemporary developments occur against the backdrop of large scale of political, economic and socio-cultural shifts. Poór and Milovecz (2011) state that the quick transition from state control and national economic planning to free market, globally competitive capitalism in Central and Eastern European region resulted in significant consequences.

- The political and administrative map of the region has undergone drastic changes (before the transition there were eight, now there are sixteen countries in the same territory).

- Due to the privatization process the private sectors has become dominant in GDP terms.

- Economic problems - the transition is followed by high inflation and decrease in output performance.

Ignjatovic and Svetlik (2003) analyzed data of 24 European countries (Cranet research from 1999/ 2000 research period) and determined four European HRM clusters:

- Nordic cluster is characterized by employee-focused HRM of medium intensity.

- The Central Southern cluster where HRM is of low intensity and mainly gives administrative support to managers.

- In the Western cluster HRM activities are intensive and professional and HRM is a strategic partner of management.

- In the Peripheral cluster (with mainly CEE countries) HRM has a low status and management-focus.

According to Poór and Milovecz (2011) after these transitional processes, the characteristics of labour market in Central and Eastern European countries are the following:

- Creation of Labour Law covering all aspects of employment first in private, later in public sector, too. 
- Ending the egalitarian pay structure as now the pay differentials are common and significant.

- End of the right to work and job entitlement as almost all CEE countries are faced with huge unemployment.

- Restructuring of social welfare systems is needed as now the employers' social security contributions (about $30-35 \%$ of the basic pay) are making the relatively cheap labour force expensive.

Based on the data of Cranet survey conducted in 2004 and 2005 in Bulgaria, Czech Republic, Estonia, Hungary, Slovakia and Slovenia Karoliny, Farkas and Poór (2009) identified the similarities in HRM practice in CEE companies. These are the following:

- Staffing (especially managerial selection) relies heavily on the company's internal resources.

- The planning and implementation of training activities is dominated by the HRM department, while the training need identification is mainly line management responsibility.

- The performance appraisal is a widespread activity and used the least for manual works.

- Local establishments have a powerful role in determining the basic pay.

- The proportion of companies with low unionization rate is high.

Long ago CEE region is well-known for its high-educated, competent and innovative but cheap labour force. Poór and Milavecz (2011) confirm that investors choose the CEE region not only because of its cheap labour but because of the skilled, blue-collar workforce, engineers, technicians and perceived higher flexibility are also important strengths of this area.

According to Ignjatovic and Svetlik (2003), findings in Northern and Western European clusters the focus is more on internal, in-company training programs and these companies send a larger portion of their employees on training programs than in two other clusters. In the Southern and Peripheral clusters, managers spend more days in training than in the Western or Nordic clusters. On the basis of the recent Cranet survey Karoliny (2010) underlines that there is a slow convergence and improvement in the rate of implementation of up-to-date techniques in training and employee development across CEE region. Especially notable are the good results in several T\&D indicators, although the methodology used in their evaluation may be subject to questioning.

\section{HUMAN RESOURCE MANAGEMENT PRACTICE IN THE RESPONDENT COUNTRIES}

\subsection{HRM PRACTICE IN BULGARIA}

Vatchkova (1997) points out that during the transitional period HRM in Bulgarian companies was taken under the strong negative pressure of following external factors:

- the decrease of GDP

- the high inflation rate

- the increase of unemployment, and

- the decrease of living standards and worsening of the quality of life.

In Bulgaria, line managers have significantly more responsibilities for decision making in the HRM filed than human resource managers. Flexible staffing practice is not popular. In the field of training, education and qualifications the system approach is not applied.

In 2005 and 2006 Takei and Ito (2007) analyzed HRM practice in Bulgaria surveying middle and middle-upper local managers. According to their research results the main 
problems were: poor recognition, unclear career path, unfair performance appraisal, poor information disclosure and sharing, one way communication flow, less participation, unfair rewards and treatment, personal preferences and interests. Based on the obtained results the authors identified the following distinctive success factors for efficient HRM activities:

- fairness, clear rules and structure

- cares, understanding and recognition

- frequent, two-way communication.

Vatchkova (2010) stressed that during the twelve years of participation in Cranet research Bulgarian organizations achieved numerous positive changes in their HRM activities. The majority of organizations have HRM units and HRM managers. There is a drastic improvement of practices for the development of strategic tools and business strategies. There is a change of HRM function from administrative to a strategic partner position. Bulgarian companies use a variety recruiting tools. Besides, there is an improvement in performanceappraisal and T\&D practice, as well as in the use of incentives.

\subsection{HRM PRACTICE IN THE CZECH REPUBLIC}

Koubek (2011) emphasize that before Second World War the Czech Republic had a very developed personnel management system. It was based on regular performance appraisal, compensation system based on performances, developed training and development methods. As a result the aims of the company were harmonized with the workers' aims and the organisations increased the employees' satisfaction and their working conditions. During the communist era the personnel became an administrative function and the decision making process was very centralized.

After the political transition the foreign companies' HRM practice significantly influenced the human resource management practice of local Czech companies', as well. This process was facilitated by modern approach of the well-educated Czech managers. But the development of modern HRM function was not easy. Human resource management was not a priority, the manger turnover was very high and the majority of CEOs did not have HRM education.

According to Cranet results the main trends in the field of human resource management in the 90's were the following:

- the majority of companies had HRM department

- in the majority of companies HRM manager was a member of the Board of the Directors

- the main HRM activity was selection, but as the majority of HRM personal was not competent they engaged external HRM consultants, mainly head-hunters

- interview was the most popular selection technique

- long term incentives were used to motivate managers but without appropriate performance appraisal systems.

Dvorakova (2005) calls attention to the HR policies and practices in public sector and stresses that HRM activities applied by Czech territorial self-government authorities rather lag behind the social need to learn and practice ethical reasoning.

\subsection{HRM PRACTICE IN HUNGARY}

The economy of Hungary is a medium-sized, structurally, politically and institutionally open economy in Central Europe and is part of the European Union's (EU) single market. Hungary experienced market liberalization in the early 1990s as part of the transition from a socialist economy to a market economy, similarly to most countries in the former Eastern 
Bloc. Farkas, Karoliny and Poór (2007) emphasize that the traditional HRM department in Hungary before transitional processes consisted of two parts: one for white collar and other for the blue collar workers. The Hungarian personnel department was supervised by the chief executive manager, who has no control over wages and only little on non-wage benefits. The personnel department was responsible for the traditional personnel functions as selection, carrier management and so on.

Now human resource management departments use various techniques, such as Assessment Centres, and invest significant sources in the process of finding the most appropriate candidates for managerial positions. On the contrary, manual workers are selected by means of more simple and inexpensive methods. One of the features of the Hungarian compensation system is that the base pay of managers is determined on an individual level, while the base pay of manual workers on industry level, based on industry-wide collective bargaining processes.

Karoliny (2010) analyzed the performance appraisal system in Hungarian companies based on the Cranet data from 2005 and 2008. She claims that appraisal is widely used, not only in large companies. However, formal evaluation is mainly used for managers and professional staff. The results of performance appraisal are utilized when identifying training needs, ways of career development and for pay determination.

Farkas, Karoliny and Poór (2011) emphasize that the private and public sector in Hungary have different demands towards human resource management and may learn from each other according to HRM efficiency and modernization.

\subsection{HRM PRACTICE IN SERBIA}

Milikić, Janićijević and Petković (2008) analyzed the position of HRM in Serbia based on interviews with HRM managers and HRM directors in 38 selected Serbian companies. They have found that the role of HRM function is very weak, but a growing number of companies are introducing HRM departments. The majority of these recently established HRM departments have limited functions - mostly performing administrative tasks. In Serbia the absence of more strategic involvement of HRM is characteristic. According to the cited authors, it is due to the lack of competences of HRM professionals, which is the result of inappropriate HRM education at university level.

Leković and Šušnjar (2009) claim that the majority of HRM responsibilities (staffing, compensation) are in the line managers' authority, but the main responsibility for these HRM issues is, indeed, in the hands of top managers.

Based on Cranet data Slavic, Susnjar, and Poór (2012) claim that in Serbia about $60 \%$ of HR directors have a place on the Board of Directors. But it is presumably not a sign of the high significance of HRM, but the result of a functional organizational structure of the majority of the examined companies. The senior HR managers in Serbia are recruited from internal sources; they are usually HR professionals from the HRM department promoted to this position. In the majority of Serbian companies, line managers are primarily responsible for main HR decisions. They make decisions about recruitment and selection, compensation and training and development, as well, alone, even without consultation with the HR managers.

Stangl and Szlávicz (2011) are on opinion that in Serbian companies in the near future the application of various selection techniques and well-planned use of training programs and compensation packages is expected, as well as, the spreading of objective performance appraisal tools. 


\subsection{HRM PRACTICE IN SLOVAKIA}

Letiche (1998) analyzed the modernization of the Slovakian society and pointed out that Slovak companies in 1990s followed opportunistic strategies, which were implicit and not verbalized. Human resources were not viewed in a manner, which transcended profit maximization.

In 2005 and 2006 Takei and Ito (2007) analyzed HRM practice in Slovakia surveying middle and middle-upper local managers. According to their research results the main problems in Slovakian organizations were: poor communication about corporate policies and strategic directions, one way communication, unstructured information channels, poor feedback from supervisors, poor information disclosure and sharing, insufficient information to do work and make decisions, ineffective meetings, unclear and unfair performance appraisal and poor coaching. Based on the obtained results the authors identified the following distinctive success factors for efficient HRM activities:

- fairness, clear rules and structure

- frequent, two-way communication, and

- disclosure, transparency and information sharing.

The research results of Blstakova (2010) show that the importance of performance appraisal is quite stable in Slovak organizations and proves no improvement in this HRM area over the last decade. Nevertheless, Slovak managers slowly began to understand the urgency of systematically composed HRM activities.

Based on the survey data on the human resource management practice of the Slovakian subsidiaries of foreign companies authors Volosin, Poór, Karoliny and Engle (2012) point out the key business issues and trends Slovakian HRM managers have to face with. They are following: efficiency improvement, company development, distribution development and company reorganization.

\subsection{HRM PRACTICE IN SLOVENIA}

Slovenia was the most developed part of former Yugoslavia. Svetlik et al (2010) claim that foreign companies coming to Slovenia have largely contributed to the spreading of modern human resource management practice. Now in the majority of companies HRM function is treated as an important one. HRM experts have become real partners to company managers. The modern HRM techniques used in market economies are widely used in Slovenian companies. Further development is expected in the field of job analysis and evaluation processes.

Svetlik, Kohont and Farkas (2011) stress out that in Slovenia HRM has a strategic role and it in the same time contributes to the increase of company efficiency and employee satisfaction. External service providers are mainly used in the field of training and development.

Based on Cranet research results Bogićijević-Milikić and Janićijević (2009) state that in Slovenian companies HRM departmants are responsible for all human resource management activities (recruiting, selection, training, employee relations, etc). About $80 \%$ of companies use performance apparaisal systems for evaluation of the work of all types of employees (managers, professionals, clericals and manual workers). The majority of Slovenian companies offer performance related pay, not only for managers, but for clerical, professional and manual workers, too. 


\section{MATHERIAL AND METHOD}

This current research is based on the Cranet data obtained in 2008/10. The Cranfield Network of International Human Resources Management (Cranet) was established in 1989 is now a collabouration of more than 40 universities and business schools, representing a country from all over the world. In this paper the authors analyze the data of the latest Cranet survey round (2008-2010), when the European sample was created by the respondent companies from 18 EU countries and five other European (Iceland, Norway, Russia, Serbia and Switzerland) countries.

In 2008/10 research period 267 Bulgarian, 54 Czech, 139 Hungarian, 50 Serbian, 225 Slovakian, and 219 Slovenian, id est altogether 954 CEE companies' HR managers filled out the Cranet questionnaire concerning various aspects of HRM function. The respondents of the CEE sample were made of companies mainly from manufacturing and service sector in private ownership, with less than 1000 employees. The EU sample consisted of 3748 companies from 18 countries, while the total European sample from 4189 companies from 23 European states. Beside Europe Cranet has data about HRM practice in USA, Japan, Taiwan, South Africa, Israel, Australia and Philippines, too, but the results of these countries are out of the focus of this current paper.

The standardized Cranet questionnaire consists of six parts: HRM activity in the organization, staffing practices, employee development, compensation and benefits, employee relations and communication and organizational details. The sample is made of HRM managers or people responsible for human resource management activities of companies with more than 50 employees. Since a comprehensive international database with all organizations is still missing, each participating country was in charge of developing a mailing list used for a paper-based and/or online survey.

The sample distribution among the industry classification shows that most of the organizations are in production, manufacturing, and other industrial sectors. The majority of the participating companies is in the private sector and employs fewer than 200 people. For the majority of the sample the main market is either national or world-wide.

The aim of this work is to present and analyze the training practices in Bulgarian, Czech, Hungarian, Serbian, and Slovak and Slovenian companies both by countries and as a particular region average and compare it to practice of companies from all EU respondents and all European region participants averages. The paper will present and analyze data indicating the:

- importance of T\&D expressed by the ratio of the annual training budget in the total payroll costs,

- extensiveness of T\&D function, characterized by annual training days per year among different type of employees and the

- effectiveness aspect of T\&D described by the most often used techniques for evaluating the T\&D function.

\section{DISCUSSION}

\subsection{PROPORTION OF ANNUAL PAYROLL COST SPENT ON TRAINING}

According to the Cranet data, companies in EU countries in average spent 3,72\% of their annual payroll cost to training and development, while for European companies this ratio average is a little bit higher: 3,93\%. As the individual and average ratios on Figure 1 indicates, the average ratio of this T\&D importance indicator in the analyzed CEE countries is 
further gap lower, than the EU counties average. In conclusion, the rank of importance of T\&D practice is as follows:

- European countries,

- EU countries,

- CEE countries.

Among the examined CEE countries in the 2008-2010 research period majority of the companies spent $2-5 \%$ of their annual payroll cost to employee training and development programs. The highest average proportion is reported from Slovakia $(4,83 \%)$ and Hungary $(4,12 \%)$, while the lowest from Czech Republic $(2,04 \%)$ and Serbia $(2,62 \%)$.

Figure 1: The proportion of annual payroll cost spent on training (\%)

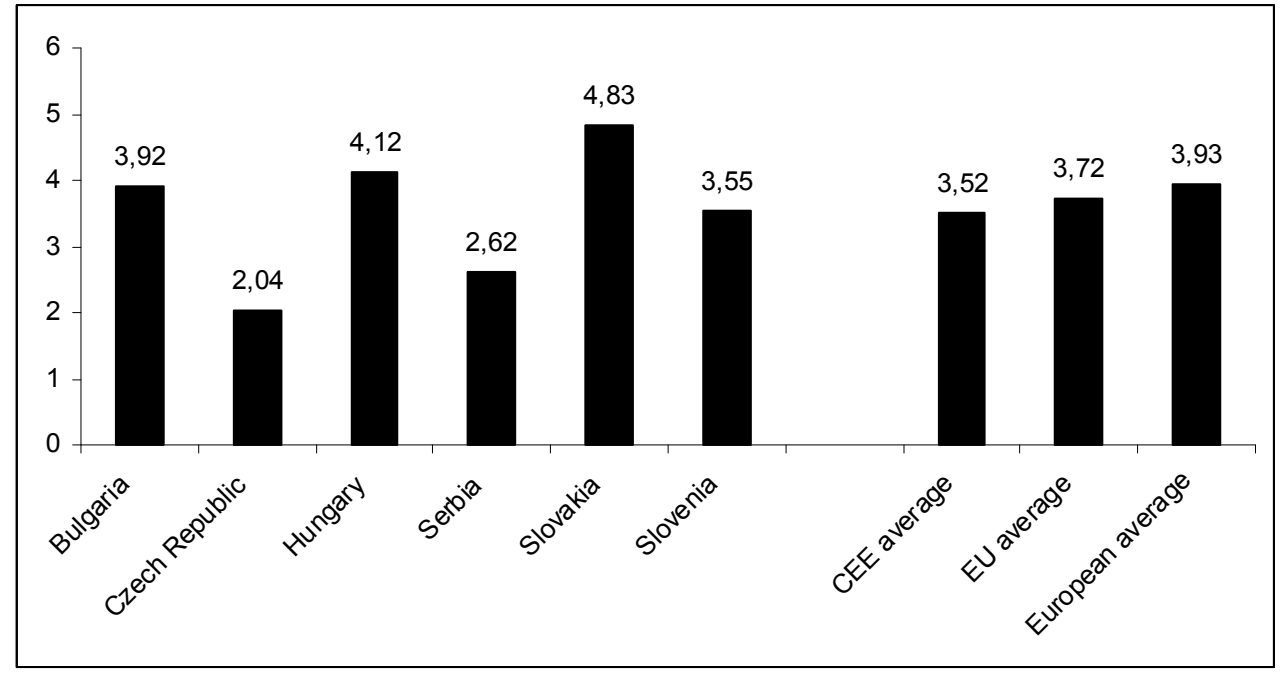

Source: Cranet data and authors' calculation

As a summary, it can be stated that on the one part there is a significant difference among CEE countries in the importance of investments into T\&D function, on the other part their average ratio is the lowest in comparison to the rest of the investigated European samples in our analyses.

\subsection{ANNUAL TRAINING DAYS}

The extensiveness of T\&D function is characterized by the indicator of training days per year offered for different employee categories. (See Table 1)

Table 1: Training days per employee

\begin{tabular}{|l|c|c|c|c|c|}
\hline \multirow{2}{*}{ Country } & \multicolumn{4}{|c|}{ Employee categories } & \multirow{2}{*}{ Average } \\
\cline { 2 - 5 } & Manual & Clerical & Professional & Management & \\
\hline \hline Bulgaria & 7,90 & 5,75 & 10,90 & 7,62 & 8,04 \\
\hline Czech Republic & 3,56 & 5,35 & 8,00 & 8,15 & 6,26 \\
\hline Hungary & 1,98 & 3,53 & 6,63 & 6,81 & 4,74 \\
\hline Serbia & 1,71 & 6,13 & 8,16 & 11,50 & 6,88 \\
\hline Slovakia & 5,50 & 7,10 & 10,45 & 10,11 & 8,29 \\
\hline Slovenia & 6,25 & 3,89 & 10,45 & 7,97 & 7,14 \\
\hline CEE average & 4,48 & 5,29 & 9,10 & 8,69 & 6,89 \\
\hline EU average & 4,14 & 4,71 & 7,88 & 7,20 & 5,98 \\
\hline Europe average & 4,11 & 4,86 & 7,88 & 7,71 & 6,14 \\
\hline
\end{tabular}

Source: Cranet data and authors' calculation 
The rank of extensiveness of T\&D is lead by the Slovakian and Bulgarian companies. On average their employees spend more than 8 (8,29 - 8,04 days/year consecutively) days on training. At Slovakian companies not only the management and professional staff members spend considerable amount of time (a little bit more than 10 days) with training, but also the clericals are receiving the highest $(7,1)$ in sample days/year and the 5,5 day offered to manuals is also substantial. In spending time on manual workers training, the highest numbers (7,9 days/year) are reported from the Bulgarian firms, where this indicator is creates the second highest average in CEE sample, with the narrowest standard deviation.

On the bottom of the rank of T\&D extensiveness indicator are the Hungarian employees, who in average spend less, than $5(4,74)$ days per year on competence-development. This average is hiding a practice, where the members in all the staff categories are receiving the lower in CEE sample time spent on T\&D and there is only one country (Serbia 1,71) in this sample, where the manuals are participating with fewer days/year in training courses than in Hungary $(1,98)$.On average the professional staff spend the most time on training, except in Czech Republic, Hungary and Serbia where managers have the most paid days off for training purposes.

It is interesting to note, that the CEE average $(6,89$ days/year) of this T\&D indicator is the highest among of our analyzed European samples. Namely while the average of all 23 European countries examined hardly exceeds $(6,14)$ the 6 days/year the EU average falls below it (5,98 days/year). In conclusion the rank of extensiveness of T\&D practice is as follows:

- CEE countries,

- European countries,

- EU countries.

\subsection{THE EVALUATION OF TRAINING EFFECTIVENESS}

Figure 2 presents the obtained data on the percentage of organizations who systematically evaluate training effectiveness (Kirkpatrick, 1994). On average less than half (47,34\%) of European companies evaluate the effectiveness of their training programs. The value of this indicator for CEE countries is a bit higher $(51,1 \%)$, while for EU states is in between $(50,5 \%)$. Among the analyzed CEE countries, there are remarkable differences. In Serbia only 36\%, while in Bulgaria and Hungary about $42 \%$ of companies evaluate their training programs, while from Czech Republic more than $72 \%$ of companies are reporting the usage of systematical training evaluation methods.

Figure 2: The percentage of organizations systematically evaluating the training effectiveness

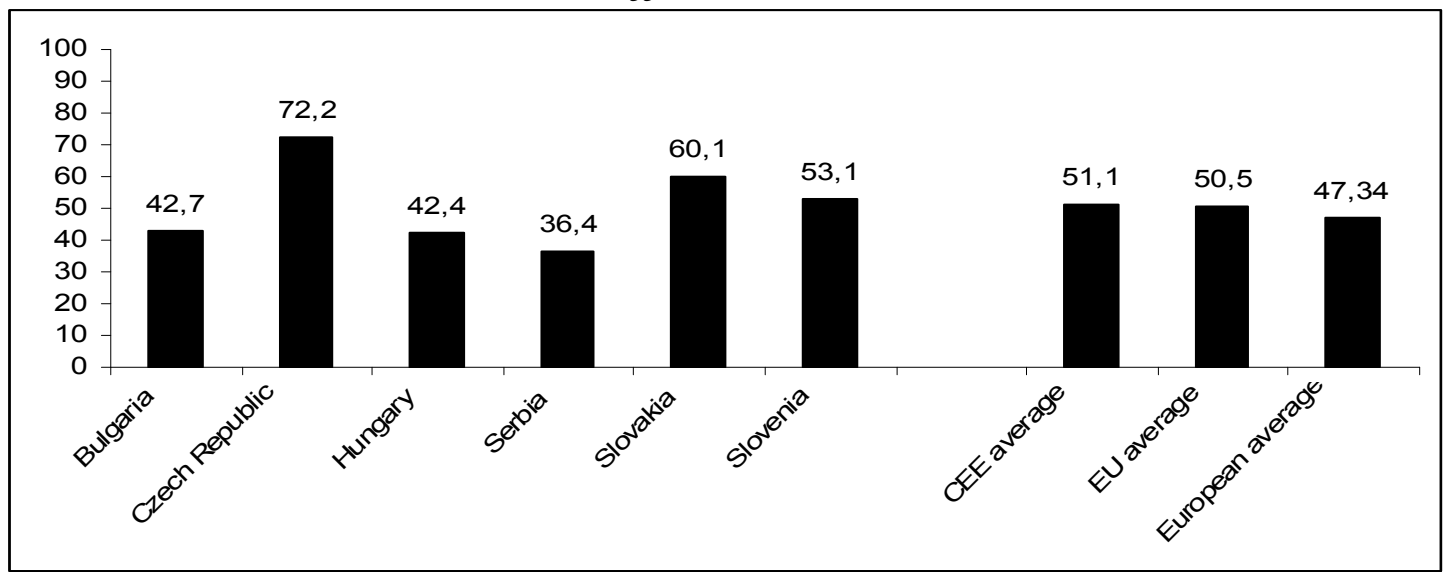

Source: Cranet data and authors' calculation 
Table 2 presents the techniques most commonly used for training evaluation.

Table 2: Techniques used to evaluate training (\%)

\begin{tabular}{|l|c|c|c|c|c|c|c|c|c|}
\hline & BG & CZ & HU & SRB & SR & SLO & CEE & EU & Europe \\
\hline \hline Training days & 48 & 60 & 52 & 45 & 57 & 79 & 57 & 52 & 50 \\
\hline Meeting objective & 63 & 88 & 86 & 83 & 76 & 87 & 80 & 80 & 78 \\
\hline $\begin{array}{l}\text { Evaluation immediately } \\
\text { after training }\end{array}$ & 59 & 94 & 86 & 69 & 73 & 79 & 77 & 83 & 82 \\
\hline $\begin{array}{l}\text { Job performance } \\
\text { immediately after training }\end{array}$ & 64 & 14 & 28 & 57 & 27 & 23 & 35 & 28 & 31 \\
\hline $\begin{array}{l}\text { Job performance several } \\
\text { months after training }\end{array}$ & 69 & 21 & 30 & 50 & 37 & 37 & 41 & 33 & 33 \\
\hline $\begin{array}{l}\text { Feedback from line } \\
\text { managers }\end{array}$ & 63 & 94 & 90 & 85 & 82 & 88 & 84 & 80 & 80 \\
\hline Feedback from employees & 55 & 79 & 90 & 73 & 77 & 88 & 77 & 77 & 75 \\
\hline Return on investments & 35 & 19 & 20 & 27 & 16 & 15 & 22 & 15 & 16 \\
\hline
\end{tabular}

Source: Cranet data and authors' calculation

Based on the obtained data one can conclude that in the CEE region the techniques for the evaluation of training effectiveness can be characterized as mainly informal, because of the rank of these are as follows: feedback from line manager (84\%), meeting objectives (80\%), evaluation immediately after training (77\%) and feedback from employees (77\%).

In the countries of the European Union the most frequently used techniques create a bit professional approach about the care for effectiveness of T\&D practices. The majority of companies namely use evaluation immediately after training $(83 \%)$, meeting objective $(80 \%)$ and feedback from line managers $(80 \%)$. In the examined European companies the most commonly used techniques are the same as in the EU. Among the analyzed CEE countries, there is a difference in the usage of techniques for evaluation training effectiveness. In Bulgaria, the most common technique is job performance several months after training (69\%). In the Czech Republic, the evaluation is immediately after training (94\%). In Hungary, the most common evaluation technique is the feedback from the line manager $(90 \%)$ and employees (90\%). In Serbia and Slovakia feedback from the line manager (83\% and 82\%), while in Slovenia feedback from the line manager and employees are used in the same percent $(88 \%)$. It must be noted that return on investment (Bohlander and Snell, 2007) is the least commonly used technique in all the CEE countries, just like in the EU and the examined European companies.

\section{CONCLUSIONS}

In the competitive and globalized world, a highly- or multi-skilled, competent labour force becomes vital factor of reaching the organizations' triple-level objectives. Organizations have to focus on different on-site and off-site training programs for all employee categories. It falls within the HRM department's cognizance to analyze the need, design, sometimes execute, and finally evaluate different training programs.

Due to its special context, HRM activities in the CEE region are different from those in the EU countries and even more distant from HRM practices in the US. The HRM tradition, economic and social situation and present HRM practice and Bulgaria, the Czech Republic, Hungary, Serbia, Slovakia and Slovenia is rather different. In Bulgaria, there is change towards a strategic role of human resource management function. HR managers use the variety of modern HRM tools. In the Czech Republic, the foreign companies had a positive influence on the development of HRM approach, but there is still place for improvement. In 
Hungary companies use modern HRM tools but there is still a significant difference between HRM practice towards managers and workers. In Serbia, the negative pressure from external environment and the elements of national culture made the development of modern HRM approach difficult. However, there are positive examples of the application of HRM principles and tools. In Slovakia, there are still serious problems in the human resource management field, but managers slowly understand the importance of the appropriate HRM approach. In Slovenia HRM function is treated as being as important as it deserves to be. In the majority of companies, human resource managers are the strategic partners of the corporate leaders and significantly contribute to the companies' success and employees' satisfaction. Multinational companies and other organizations tending to cooperate with CEE partners have to be aware of the specialties of HRM activities in former socialist countries.

In this paper, the authors focused on the training activity of companies from six CEE countries: Bulgaria, Czech Republic, Hungary, Serbia, Slovakia and Slovenia based on the Cranet research data from 2008/10. The archetype companies from these CEE countries spend between two and five percentages of their annual payroll costs on training. The CEE average is 3,52\% - a bit behind the EU and European average of about 4\%. Companies in the Czech Republic and Serbia spend about 2\% for training purposes, while in Slovakia employers are more generous as they invest almost $5 \%$ of payroll costs on training. It can be stated that the importance of T\&D activity expressed by the annual training budget is the lowest in CEE region compared to EU and other European countries examined. In the same time, there are significant differences among the six CEE countries in this aspect.

On average the employees spend seven days on training in CEE, which is very similar to the EU and European value of six days. In Bulgaria, Slovakia and Slovenia professional staff, while in Hungary, Serbia and the Czech Republic managers spend the most time on training programs. The extensiveness of T\&D activity is the highest in CEE region compared to EU and examined European companies. The effectiveness of T\&D function is low, as on average only $51 \%$ of analyzed companies in CEE region systematically evaluate their training programs. In Serbia, Bulgaria and Hungary this indicator is about $40 \%$, while in the Czech Republic it is more than $70 \%$. In CEE region the T\&D evaluation is mainly informal, as the most common methods are feedback from the line manager, meeting objectives, evaluation immediately after training and feedback from employees.

Even though in all six CEE countries the modern HRM approach is accepted, there is still space for development. Improving the importance and extensiveness of training activity as well as its effectiveness may contribute to the more effective organizational knowledge acquisition, to the more advanced HRM activities and to the companies' overall success, too.

\section{REFERENCES}

1. Armstrong M. (2007): A handbook of human resource management practice. Kogan Page, London.p.982.

2. Blstakova. J. (2010): Employees' appraisal as an indicator of the quality of human resources management. Megatrend Review. Vol. 7. No. 2. pp. 79-99.

3. Bogicijevic-Milikic, B. - Janicijevic N. (2009): HRM trends in transitional economies: two reflections of the shared background. Sociologija, Vol. 51, No.2. pp. 158-176.

4. Bohlander, G. - Snell, S. (2007): Managing Human Resources, Thomson. Mason. p. 781.

5. Brewster, C,.- Morley, M. - Buciuniene, I. (2010): The reality of human resource management in Central and Eastern Europe - A special issue to mark the 20th anniversary of Cranet (Cranfield Network on Comparative Human Resource Management). Baltic Journal of Management, Vol 5, No 2, pp. 145-155. 
6. Dvorakova, Z. (2005): Encouraging ethical behavior in public administration by human resource management. Journal of Business Economics and Management. Vol. 6. No. 3. pp. 171-178.

7. Farkas, F. - Karoliny, M-né. - Poór, J. (2007): Human resource management in Hungary in light of Eastern European and global comparison. Working Paper Series, 1 (1) pp. 1-42.

8. Farkas, F. - Karoliny, M-né. - Poór, J. (2011): A HR hatékonysága Magyarországon (The HR efficiency in Hungary) In: Trendek és tendenciák a kelet-európai emberierőforrásmenedzsmentben (Trends and tendencies in the Central and Eastern European HRM) (eds: Poór, J -Bóday, P. - Kispál-Vitai, Zs.) pp. 176-195.

9. Ignjatovic, M. - Svetlik, I. (2003): European HRM clusters. EBS Review, No 17, pp. 2539.

10. Karoliny Zs. (2010): Developments in Hungary in the key function of Human Resources Management: T\&D. In. 11th International Conference on Human Resource Development Research and Practice across Europe. June 2-4, 2010, Pecs (Hungary) pp. 1-11.

11. Karoliny, Zs.- Farkas, F. - Poór, J. (2009): In focus: Hungarian and Central Eastern European characteristics of human resource management - an international comparative survey. Journal for East European Management Studies (JEEMS), Vol. 14, No. 1, pp. 948.

12. Kirkpatrick, D. L. (1994): Evaluating Training Programs: The Four Levels. BernettKoehler. San Francisco. p.373

13. Koubek, J. (2011): HR a Cseh Köztársaságban (HRM in the Czech Republic) In: Trendek és tendenciák a kelet-európai emberieröforrás-menedzsmentben (Trends and tendencies in the Central and Eastern European HRM) (eds: Poór, J - Bóday, P. - Kispál-Vitai, Zs.) pp. 102-126.

14. Lekovic, B. - Susnjar, S.G. (2010): Learning, education and development in comparative human resource management. Strategic Management, Vol. 15, No 4, pp. 53-74.

15. Letiche, H. (1998): Transition and human resources in Slovakia. Personnel Review. Vol. 27. No. 3. pp. 213-226.

16. Mayrhofer, W., - Sparrow, P. - Brewster, C. (2012): European human resource management: a contextualized stakeholder perspective. In: Brewster C. and Mayrhofer W. (eds). Handbook of research on comparative human resource management. Edward Elgar, Cheltenham (UK): pp. 528-549.

17. Milikić, B. B. - Janićijević, N. - Petković, M. (2008): HRM in transition economies: The case of Serbia. SEE Journal. Vol. pp. 75-88.

18. Morley, M., - Minbaeva, D. - Michailova, S. (2012): The transition states of Central and Eastern Europe and the Former Soviet Union. In: Brewster C. and Mayrhofer W. (eds). Handbook of research on comparative human resource management. Edward Elgar, Cheltenham (UK) pp. 550-575.

19. Nikandrou, I.-Apospori, E. - Papalexandris, N. (2005): Changes in European HRM - A longitudinal comparative study among 18 European countries. Journal of European Industrial Training, Vol. 29, No 7. pp. 541-560.

20. Perez, H. - Casp,i A. (2011): Training and Development. In: Cranet survey on Comparative Human Resource management - International Executive Report 2011. Cranet. Cranfield. p. 97.

21. Poór, J. - Milavecz, Á. (2011): Management consulting in Human resource management: Central and Eastern European perspectives in light of empirical experiences. Journal of Service Science and Management, No 4, pp. 300-314.

22. Slavic, A. - Susnjar, S.G. - Poór, J. (2012): The role of Human resource management in Serbian and Hungarian Companies: results from the Cranet 2008/9 survey. Management Re-Imagined - Programme and Proceedings of the $11^{\text {th }}$ World Congress of the 
International Federation of Scholarly Associations of management. (ed.: Morley, M.). University of Limerick, Interesource Group Publishing. Limerick. CD-ROM.

23. Stangl, G. - Szlávicz, Á. (2011): Az emberierőforrás-menedzsment helyzete Szerbiában. (The position of human resource management in Serbia). In: Trendek és tendenciák a kelet-európai emberieröforrás-menedzsmentben (Trends and tendencies in the Central and Eastern European HRM) (eds.: Poór, J - Bóday, P. - Kispál-Vitai, Zs.) pp. 232-251.

24. Stavrou, E.T. - Brewster, C. (2005): The configurational approach to linking strategic human resource management bundles with business performance: myth or reality? Management Revue, Vol. 16, No 2, pp. 186-201.

25. Svetlik, I. et al. (2010): Human resource management in the countries of former Yugoslavia. Review of International Comparative Management. Vol. 11. No. 5. pp. 807833.

26. Svetlik, I. - Kohont, A. - Farkas, F. (2011): HR Szlovéniában (HR in Slovenia). In: Trendek és tendenciák a kelet-európai emberierőforrás-menedzsmentben (Trends and tendencies in the Central and Eastern European HRM) (eds.: Poór, J and Bóday, P. and Kispál-Vitai, Zs.) pp. 265-276.

27. Takei, H. - Ito, Y. (2007): Human resource management and governance in Central and Eastern Europe: case studies in Bulgaria and Slovak Republic. Policy and Governance Working Papers. No 119. pp. 1-28.

28. Vatchkova, E. (1997): Human resource management in Bulgaria during the transition to market economy. European conference: Human resource management in Europe: Trends and challenges, Athens

29. Vatchkova, E. (2010): Human resource management in a global environment. Lambert Academic Publishing. p.284.

30. Volosin, M. - Poór, J. - Karoliny, M-né. - Engle, A. D. (2012): Slovakia. In. Human resource management issues and challanges in foreign owned companies: Central and Eastern Europe. (eds.: Poór, J. - Farkas, F. - Engle A.D.) Komárom/Komarno-GödöllöPécs. p.317. 